This item was submitted to Loughborough's Research Repository by the author.

Items in Figshare are protected by copyright, with all rights reserved, unless otherwise indicated.

\title{
Career anchors and preferences for organizational career management: A study of information technology professionals in three European countries
}

\section{PLEASE CITE THE PUBLISHED VERSION}

https://doi.org/10.1080/09585192.2017.1380058

\section{PUBLISHER}

Taylor \& Francis (Routledge)

\section{VERSION}

AM (Accepted Manuscript)

\section{PUBLISHER STATEMENT}

This work is made available according to the conditions of the Creative Commons Attribution-NonCommercialNoDerivatives 4.0 International (CC BY-NC-ND 4.0) licence. Full details of this licence are available at: https://creativecommons.org/licenses/by-nc-nd/4.0/

\section{LICENCE}

CC BY-NC-ND 4.0

\section{REPOSITORY RECORD}

Arnold, John, Crispin Coombs, and Martin Gubler. 2019. "Career Anchors and Preferences for Organizational Career Management: A Study of Information Technology Professionals in Three European Countries". figshare. https://hdl.handle.net/2134/26562. 
Career Anchors and Preferences for Organizational Career Management: A Study of Information Technology Professionals in Three European Countries

\author{
John Arnold \\ Professor of Organisational Behaviour \\ Loughborough University, School of Business and Economics \\ School of Business and Economics \\ Loughborough University \\ Leicestershire, UK LE11 3TU \\ +44 (0)1509 228007 \\ j.arnold@lboro.ac.uk \\ Crispin R Coombs ${ }^{*}$ \\ Reader in Information Systems \\ Loughborough University, School of Business and Economics \\ Epinal Way \\ Loughborough \\ Loughborough, Leicestershire, UK LE11 3TU \\ +44(0)1509228835 \\ c.r.coombs@lboro.ac.uk \\ Martin Gubler \\ The Schwyz University of Teacher Education \\ Zaystrasse 42 \\ CH-6410 Goldau \\ Zurich, Switzerland \\ +414185905 55 \\ martin.gubler@phsz.ch \\ *Corresponding author
}




\section{Career Anchors and Preferences for Organizational Career Management: A Study of Information Technology Professionals in Three European Countries}

Careers research has moved beyond the notion of traditional careers in a stable, predictable work environment to a more individual perspective. However, individual agency in career management is still likely to involve interactions between organizations and individuals. This is particularly evident in organizational career management (OCM). Career anchor theory has shed light on the work preferences of professionals but little research has examined relationships between career anchors and how people enact their careers, or how these constructs and their relationships might differ between countries. We report a quantitative study of 1,629 IT professionals from 10 organizations in Switzerland, Germany and the UK. After allowing for control variables, career anchor scores explained statistically significant amounts of variance in preferences for five of the six categories of OCM practices. Some of the connections between career anchors and OCM preferences followed naturally from their content, but others were less self-evident, or even seemingly contradictory. There were some significant differences between nationalities, with the UK tending to be the outlier. These differences were partly but not entirely consistent with prior research. This study expands understanding of the interplay of individual values and OCM and draws on previous work to offer a new classification of OCM practices.

Keywords: Career anchors, information technology professionals, organizational career management, European, cross-cultural 


\section{Introduction}

The majority of careers research has moved beyond the notion of traditional careers in a stable, predictable work environment to a more individual perspective, emphasizing the transferable skills individuals need to navigate their careers within their professions, and not necessarily within their current organizations (Sullivan \& Baruch, 2009). However, contemporary career concepts that emphasize individual agency in career management, such as the 'Boundaryless Career' (Arthur \& Rousseau, 1996) and 'Protean Career' (Hall, 2002) are still likely to involve links between organizations and individuals, albeit in a less structured or permanent way (Baruch \& Peiperl, 2000). Thus, there is a need to go beyond the 'traditional' versus 'contemporary' debate in the careers literature, and investigate how individual and organizational viewpoints can be combined to better understand and meet people’s career needs.

One area where the link between individual and organizational viewpoints is particularly evident is organizational career management (OCM). OCM is the process of an organization carrying out activities that are relevant to the career development of its employees (Baruch \& Peiperl, 2000). OCM practices include performance appraisals, formal mentoring, development centers, secondments, training and many others (Lewis \& Arnold, 2012; Baruch \& Peiperl, 2000). The current trend in the development of career systems is to allow higher flexibility and diversity with an emphasis on individuals (Baruch, 2004). Lips-Wiersma and Hall (2007) add that career management is no longer a simple HR function and requires a systemic approach that can respond to the needs of the individual as well as integrating with organizational requirements.

However, research indicates that there are major deficiencies in OCM with many companies only implementing very narrow and limited career management practices (Scholarios et al., 2008). Doyle (2000) found that inadequate or bad OCM causes cynicism amongst employees. For example, in their study of Indian IS workers, Lacity, Iyer, \& Rudramuniyaiah (2008) describe how some interviewees viewed career development skeptically, suggesting that personal career objectives would only be supported if they fitted with organizational 
requirements. Sturges, Conway, \& Liefooghe (2008) and Sturges, Guest, Conway, \& Mackenzie Davey (2002) report that if OCM practices are implemented effectively it is possible to create a 'virtuous circle' where career management by individuals and organizations build constructively on each other. Hirsh and Jackson (2004) caution that it is better to operate a small number of career management practices well than many poorly.

A challenge for HR managers is to know which OCM practices to prioritize (Crawshaw \& Game, 2015). It has been argued that one way employers can increase the effectiveness of their OCM practices is to take more account of the variety of personal needs or career anchors of employees (Schein \& Van Maanen, 2016; Hall, Briscoe, Dickmann, \& Mayrhofer, 2012; Jiang, Klein, \& Balloun, 2001). In this paper we put this proposition to the test by empirically examining whether scores on a career anchors measure are associated with preferences for OCM practices. We also examine whether career anchors and OCM preferences vary between three European nationalities. We use data from a large sample of IT professionals working in European organizations.

\section{Career anchors}

Edgar Schein (1978) introduced the concept of career anchors. In his view, the early stages of a career expose individuals to a variety of job challenges that eventually enable them to develop a career self-concept, the so-called career anchor. Schein (1978, p. 125) defined the three components of a career anchor as: 1) self-perceived talents and abilities; 2) self-perceived motives and needs; and 3) self-perceived attitudes and values. Schein's (1978) career anchors include Technical/Functional Competence (TF) for individuals who are primarily excited by developing and using their specialist skills; Managerial Competence (MC) for those who mainly like organizing and leading people to achieve common goals; Security and Stability (SS) for individuals primarily motivated by job security and long-term attachment to one organization; Entrepreneurial Creativity (EC) for those motivated by the need to create and grow something 
that is entirely their own project; Autonomy/Independence (AI) for individuals who want to set their own work schedule and goals; Service/Dedication to a Cause (SD) for those seeking alignment between work and personal values about service to others; Pure Challenge (PC) for individuals who are primarily motivated to overcome major obstacles; and Lifestyle (LS) for those seeking work which fits well with their non-work life. In their work on IT professionals, Igbaria and Baroudi (1993) found that it is possible to split the security anchor into job security (JS) and geographic security (GS). Subsequent studies have suggested further potential anchors (Chang, 2010; Ituma \& Simpson, 2007). However, these studies build upon or adapt—rather than replace - the structure suggested by Schein. Thus, we retain Schein's structure for our study while incorporating the refinement (i.e. splitting the security anchor) advocated by Igbaria and Baroudi (1993).

Existing research on career anchors addresses several issues. One set of studies has examined the existence, nature, and number of anchors (e.g. Rodrigues, Guest \& Budjanovcanin, 2013; Wils, Wils \& Tremblay, 2010; Danziger, Rachman-Moore \& Valency, 2008; Suutari \& Taka, 2004; Feldman \& Bolino, 1996; Igbaria \& Baroudi, 1993). Another, related, strand of research concerns the testing and development of measures (e.g. Lazarova, Cerdin, \& Liao, 2014; Sarchielli \& Toderi, 2007; Igbaria \& Baroudi, 1993). A third group of studies examines the relationships between career anchor preferences and other psychological constructs such as job/career satisfaction, intention to turnover, organizational commitment, and personality (e.g. Coetzee, Schreuder, \& Tladinyane, 2014; Guan, Wen, Chen, Liu, Si, \& Liu, 2014; Chang, Jiang, Klein, \& Chen, 2012; Wils, \& Tremblay, 2005; Mignonac \& Herrbach, 2003; Agarwal, De, \& Ferratt, 2002; Wynne, Ferratt, \& Biros, 2002; Jiang, Klein, \& Balloun, 2001; Martineau, Nordvik, 1996). A fourth set of studies overlaps somewhat with the previous ones, and reports examinations of the career anchors of IT workers, who have been a popular group in career anchor research (e.g. Quesenberry \& Trauth, 2012; Ituma \& Simpson, 2007; Crook \& Crepeau, 1997; Igbaria, Meredith, \& Smith, 1995; Jiang, Klein, \& Balloun, 1995). 
However, there has been very little research on the relationships between career anchors and how people enact their careers. Partial exceptions to this are studies of turnover intention (e.g. Guan et al., 2014; Chang et al., 2012). Also, Gubler, Biemann, Tschopp and Grote (2015) examined links between current career anchor scores and past career trajectories, and found relatively few connections, though the managerial competence anchor was associated with hierarchical level and number of subordinates. These studies focus on past or future behavior rather than the processes and activities that lead to it. If career anchors are significant in driving career development it should be possible to discern relationships between them and what people seek to do to manage their careers, including utilizing OCM practices. In this study we break new ground in career anchor research by examining how anchors relate to preferred OCM practices.

\section{OCM practices}

There is an almost bewildering choice of practices for OCM available to organizations (Arnold 1997). A small number of studies have attempted to provide comprehensive lists and/or typologies of OCM practices (Lewis \& Arnold, 2012; Baruch \& Peiperl, 2000; and in the context of IT Agarwal \& Ferratt, 2002;1999). Baruch and Peiperl (2000) investigated the use of 17 OCM practices as reported by HR managers in 194 UK companies. From their empirical analysis, Baruch and Peiperl proposed a typology comprising five groups of OCM practices: basic, active planning, active management, formal and multi-directional. Adopting this typology, Lewis and Arnold (2012) have provided a more recent list of 20 OCM practices in use at 41 retail companies.

In the IT literature, Agarwal and Ferratt (2002;1999) attempted to catalog recruitment and retention practices for IT professionals across 32 US companies selected for their success in managing the IT human resource and/or business performance. They proposed a taxonomy of eleven IT retention practices. Although not solely focused on OCM, Agarwal and Ferratt's (1999) taxonomy includes six categories of OCM practices that are useful for our purposes: 
employability, training and skill development; longer-term business and leadership development; opportunities for advancement; performance measurement; sense of community; and work arrangements. We drew on all three studies (Lewis \& Arnold, 2012; Baruch \& Peiperl, 2000; Agarwal \& Ferratt, 1999) to identify specific OCM practices and then adapted Agarwal and Ferratt's (1999) taxonomy to categorize these practices. This is explained further in the Method section.

\section{Linking career anchors and preferences for OCM practices}

There are theoretical reasons to expect that career anchors and preferred OCM practices might be connected. As long ago as the middle of the $20^{\text {th }}$ century, Donald Super (1953) amongst others referred to career as a process of self-concept formation and then implementation. As noted already, more recent notions of protean and boundaryless careers also place emphasis on selfexpression, but they extend further to the capacity to learn, develop and change in response to changing conditions. Career anchors are an expression of key parts of a person’s self-concept, because they are made up of work-related values, needs, and/or skills. They are therefore not just the background context to a person's career. Instead, they form a driving force for career choices, goals and actions (Schein, 1978). Also, career anchors combine elements that are typically associated with traditional and contemporary views of career. For example, whilst the 'managerial competence’ and ‘job security’ anchors may correspond well to notions of traditional careers, ‘service/dedication’, ‘pure challenge’, ‘autonomy/independence’ or 'lifestyle’ can easily be linked to contemporary career concepts. Hence, the career anchor construct offers a perspective on careers that goes beyond the 'traditional' versus 'contemporary' debate. With a primary focus on individuals’ subjective career, anchors are a potentially powerful tool for bridging that dichotomy, for explaining individual career behavior and for suggesting organizational action in managing careers. 
Analyses of career exploration as a lifelong process (e.g. Zikic \& Hall, 2009) and career self-management as a necessary activity especially in an uncertain world (Inkson, Dries, \& Arnold, 2014, chapter 12; Abele \& Wiese, 2008) explicate the processes that occur when people seek to develop their careers. This includes the formation of goals, specification of a strategy to achieve those goals, and implementation of that strategy (e.g. Greenhaus, Callanan, \& Godshalk, 2009, chapter 2). Although usually designed primarily to achieve organizational goals (De Vos \& Dries, 2013), OCM practices can also be used by individuals to help achieve their personal goals, and thus play a part in the implementation of personal as well as organizational career strategies. Depending on the OCM practice and what an individual wants, this might be via learning more about potential job opportunities, making oneself visible to people who are in a position to influence one’s career, identifying roles that fit with one’s career anchors, crafting the present role (Wrzesniewski \& Dutton, 2001) to achieve a better fit, developing new skills to stay marketable, learning how to operate in a particular organization, and many other possibilities (Baruch, 2004; Arnold, 1997).

Schein (1996; 1990; 1978) and Schein and Van Maanen (2016) have offered a number of observations and speculations about how different anchors might be addressed by organizations in times of rapid technological, labor market and organizational change. There is still a dearth of empirical studies examining the relationship between career anchors and OCM practices. However, there are notable exceptions, such as Giles and West’s (1995) study that reported individuals with high scores on the security/stability (SS) anchor showed lower levels of proactive career planning than individuals with low scores on this anchor. Despite the lack of specific studies, wider related research provides some evidence to suspect a number of associations will be found between anchor scores and preferences for OCM practices. For example, especially in a field with rapid technological changes, high scores on the technical functional anchor (TF) are likely to associate with preferences for OCM practices that offer the most opportunities to develop and maintain technical skills that are crucial to IT jobs now and in 
future (Chang et al., 2012; Scholarios et al., 2008). This is because people who score high on the technical/functional anchor value being experts. For different reasons, IT professionals who value job security and/or geographical security might also value these kinds of interventions, because they help to keep them employable (Mgaya, Uzoka, Kitindi, \& Shemi, 2009). In contrast, IT professionals with strong managerial competence (MC) anchor scores often view their early technical positions as stepping-stones to managerial positions (Chang et al., 2012). As a result, such individuals may select OCM practices that help them to strengthen their position within an organization (Gubler, Arnold, \& Coombs, 2014; Reich \& Kaarst-Brown, 1999), and develop their leadership skills (Hsu, Chen, Jiang, \& Klein, 2003). Professionals with strong scores on autonomy/independence (AI) may be suspicious of OCM practices that may appear be designed to align them to the organization's agenda such as performance reviews, but more favorably disposed to practices that help them 'do their own thing', such as informal networks (Feldman \& Bolino, 1996). We might also expect high scorers on service/dedication (SD) to be uninterested in OCM practices that focus on advancement through the organization because that could compromise their values of service to others (Schein \& Van Maanen, 2016). Thus, our primary research question is:

RQ1: How do individuals' preferences for OCM practices vary with their career anchors?

\section{Differences between nationalities}

Questions are frequently raised regarding whether career and HRM practices can and should be applied universally or whether they need to be contextualized to fit the norms of local organizational and/or national culture (Yarnall, 1998; Brewster \& Mayrhofer, 2012). Strong arguments have been made for the contextualist position regarding the way careers are perceived, enacted and organized (Shen et al., 2015; Briscoe, Hall \& Mayhofer, 2012). This study focuses on three economically strong European countries with their specific cultural contexts, namely Switzerland, the United Kingdom (UK) and Germany. These countries have featured in some 
previous research (see below), which enables us to compare our findings with others. In Hofstede’s (2001) terms, they are very similar on power distance (low) and masculinityfemininity (quite masculine), whilst differing somewhat in uncertainty avoidance (United Kingdom somewhat lower) and individualism (United Kingdom somewhat higher). If our data show differences between even these relatively similar (though not identical) cultures, this would suggest that national culture has to be taken into account when considering career anchors and organizational career management.

Extrapolating from Derr and Laurent’s (1989) work using Derr’s career orientations, it might be inferred that UK managers value the managerial competence and autonomy anchors more than German managers, whilst the reverse is true for the lifestyle anchor. Davoine and Ravasi (2013) found that differences between Latin, Germanic and Anglo-Dutch models of management careers tend to persist even in an increasingly globalized context. For example, the Germanic model places relatively high emphasis on systematic training and development within one or a small number of organizations, which might suggest that German respondents would particularly value OCM practices that facilitate their organization-specific development and skills. In contrast the British model places more weight on assessment of performance and potential. Davoine and Ravasi comment that due to its geographical position and presence of managers from various cultural backgrounds, a Swiss model is difficult to identify.

This last point is supported in a different context by Gerber, Wittekind, Grote, Conway and Guest (2009) who analyzed different career orientations amongst large samples of Swiss German, Swiss French and British respondents. They found differences within Switzerland as well as between Switzerland and Britain. The distinctively British career orientations relative to the other two groups were a high value on job security (as opposed to employability in a range of jobs) and staying a long time in one organization, but also a relatively low importance of work and career in the context of life as a whole, and a low commitment to organizations. This might suggest that in the present study UK respondents will place a greater emphasis than others on the 
lifestyle and job security anchors, and value OCM practices that enable them to cement their place in the organization without necessarily engaging in a lot of training and development. Differences between Swiss French and Swiss German respondents were less marked but the latter were somewhat more likely to view career as central to life and feel commitment to the organization relative to self.

More generally, various intercultural studies on career anchors have clearly documented context-specific differences between countries and cultures. However, such studies have usually focused on comparing the US with other countries, for example, Australia (Schein, 1984), Taiwan (Chang, 2010) and Nigeria (Ituma \& Simpson, 2007). With a few notable exceptions such as Gerpott, Domsch and Keller (1988), who compared anchors of British, German and US R\&D professionals, studies with a focus on country comparisons outside the US have been rare. Yet, Gerpott et al.’s (1988) study found cultural differences in anchor preferences even between European countries. German engineers, for example, were significantly less technically oriented than UK engineers. To date, however, anchor differences outside the US have remained underresearched.

To explain such country-specific differences, several authors have built on intercultural typologies and models. For example, Ituma and Simpson (2007) argued that Hofstede’s (2001) framework helped to understand that the highly "masculine” values of the Nigerian culture may have led to their finding of a Nigerian-specific anchor ("being marketable”) and the almost complete lack of an original anchor in the Nigerian context (“service and dedication”). Beyond the work sphere, Magun, Rudnev and Schmidt (2016) have recently used Schwartz’s (2008) typology of values to identify clusters of people exhibiting different combinations of the values. They estimated that the proportion of people emphasizing personal growth (a combination of openness to experience and benevolence) is considerably higher in Switzerland than the UK, with Germany in the middle. The reverse pattern is identified for what Magun et al. label as 'weak social focus', which means a moderate preference for conformity, security, achievement and 
power. This might suggest that UK respondents will score highest on the job security and managerial competence anchors, and perhaps favor OCM practices that not only help them consolidate their position in the organization, but also advance in it.

This existing literature might give us some reason to expect differences between nationalities in career anchor and OCM practice preferences as noted above (for example, UK citizens might place more emphasis on job security than German or Swiss). However, it is far from conclusive due to the wide variety of countries and constructs examined, so there is not a critical mass of evidence about the countries and constructs assessed in this study. For example, regarding constructs Yarnall (2008, p. 208) points out that although orientations and anchors can to some extent be mapped onto each other, they are not the same (c.f. Rodrigues et al., 2013). Hence it is difficult to form specific expectations about how the connections between career anchor scores and OCM practice preferences will differ between nationalities. We therefore pose our second research question:

RQ2: What differences between nationalities exist in anchors, preferences for OCM practices and the associations between them?

\section{Method}

The research questions are addressed by a large empirical study in the context of the Information Technology (IT) industry in Europe. Several studies have reported that IT professionals are not significantly different from other occupational groups in terms of the motivators of productive work behavior (Ferratt \& Short, 1986), antecedents of turnover (Joseph, Boh, Soon, \& Slaughter, 2007), Myers Briggs Type Indicator (MBTI) profiles (Kaiser \& Bostrom, 1982) or career anchors (Chang, 2010; Ituma \& Simpson, 2007; Igbaria et al., 1995; Igbaria \& Weaver McCloskey, 1996). The findings of these studies provide strong evidence to suggest that IT professionals represent a suitable occupational group to investigate individual workers’ preferences for OCM practices. 


\section{Design and procedure}

As part of a wider study of career orientations of IT professionals in Europe, an online questionnaire was distributed to 3,817 IT professionals across 10 different organizations in Switzerland, the UK and Germany. The sample was chosen to cover a heterogeneous range of IT employment settings and roles, and to include a range of different organizations. They were selected from a variety of industries in the private and public sectors. They ranged from small start-up companies to large multi-national corporate firms. Including a balanced mix of different organizations helped to limit potential bias in the sample. For example, in large organizations traditionally oriented individuals may be over-represented (Smith-Ruig, 2008). The generation of a large multinational sample also allowed for multivariate analysis including control variables, as well as a comparison of cross-cultural differences within Europe. The large sample also made it possible to generalize the findings, thereby providing a better understanding of phenomena at a general economic/societal level.

With each participating organization (either IT companies or IT departments in large nonIT organizations), at least two meetings were held with senior IT HRM representatives and IT line managers prior to the survey to discuss the objectives and the design of the study. This also included the clarification of the participant selection process to ensure that only participants in IT-related functions were contacted. IT contractors were excluded from the survey, as they were unlikely to have access to OCM practices. We surveyed employees (managers as well as nonmanagers) in IT-related roles in the ten participating organizations (either IT companies or IT departments in large non-IT companies). The survey was sent to potential participants directly by the HR department or the top management in each organization. The same procedure was used for subsequent reminder emails. As organizations did not know who responded to the survey and the research team was not supplied with any contact information for their IT professionals, participants were able to preserve their anonymity. 
The survey was provided in three languages; English, German and French. All items were first developed in English. The translation comprised four steps of translation and re-translation consistent with previous research using multi-lingual approaches (Chudzikowski et al., 2009). To ensure that participants from all countries had a common understanding of all scale items, each OCM practice was briefly explained in a help menu, based on commonly used definitions and descriptions. This help menu was available in English, German and French to make sure every participant could read it in a language he/she was highly familiar with to minimize potential misunderstandings.

\section{Measures}

To measure career anchors, Igbaria and Baroudi’s (1993) instrument with 25 items was used in its original form. No changes were made to the item order or the response format, a five-point Likert scale (scores 1-5, with a high score indicating endorsement of the anchor). This decision was taken as the scale had been developed, thoroughly tested and validated in the context of IT professionals. In his original work, Schein (1978) argued that each individual would develop just one dominant anchor. This view has now been rejected (e.g., Chang, Chen, Klein, \& Jiang, 2011). Thus, we used mean scores to assess an individual's orientation to each anchor.

This instrument assessed nine anchors. To ensure satisfactory levels of discriminant validity a confirmatory factor analysis of the career anchor data was conducted using AMOS version 23 (Arbuckle, 2014). It showed that the nine anchor model was a good fit to the data, with all 25 questions loading significantly on their designated anchor (median standardized loading $=0.75$, range 0.43 to 0.89 ). The latent variables representing the anchors were not strongly correlated with each other (the highest was between Managerial Competence and Entrepreneurial Creativity at 0.49 , and the median correlation between pairs of anchors, ignoring sign, was 0.21). Overall model fit indices are RMSEA $=0.05, \mathrm{CFI}=0.92, \mathrm{NFI}=0.91$ and $\mathrm{TLI}=$ 0.90. All these results meet or exceed the thresholds recommended by most analysts (e.g. Byrne, 
1994; Browne \& Cudeck, 1989). Therefore it was decided to use the original structure with nine anchors in this study. Cronbach alpha reliability coefficients were generally acceptable or better, and similar to those reported by Igbaria and Baroudi (1993): Technical/Functional Competence $($ alpha $=0.68)$; Managerial Competence $($ alpha $=0.80)$; Geographical Security $($ alpha $=0.83)$; Job Security (alpha = 0.76); Entrepreneurial Creativity (alpha = 0.88); Autonomy/Independence $($ alpha $=0.66)$; Service/Dedication (alpha $=0.77)$; Pure Challenge (alpha $=0.62)$; and Lifestyle (alpha $=0.66)$.

To identify and categorize OCM practices, we drew on prior literature in HRM and IT, an approach inspired by Ferratt et al.’s (2005) study on IT human resource configurations. We began with the OCM practices identified by Baruch and Peiperl (2000) and Arnold and Lewis (2012) and mapped the practices onto one another, shown in the first two columns in Table 1 . Then we consulted Agarwal and Ferratt (2002;1999) who studied retention practices for IT professionals, to add further OCM practices and ensure the practices were appropriate to the IT context. From this analysis nineteen OCM practices were selected for study.

[Take in Table 1 near here]

To classify the OCM practices, the three members of the research team drew on their individual domains of expertise in (respectively) career research, information systems career research, and being an IT career management practitioner in a multi-national corporation. The members convened to compare their independent categorization decisions to identify levels of agreement or disagreement. The three research team members independently assigned fifteen (79\%) of the OCM practices to the same category in Agarwal and Ferratt’s (1999) elevencategory taxonomy. In all other cases two raters assigned an OCM practice to one category and the other rater assigned it to another category. A measure of inter-rater agreement, Fleiss’ kappa (Fleiss, 1971) was calculated. This statistic is suitable where there are more than two raters classifying the same data using the same coding categories. Kappa was 0.737 , which is normally considered a high level of agreement, though there is no generally accepted benchmark because 
the ease of obtaining a high level of agreement partly depends on the number of categories. In this case that number (11) was quite high, so we can have confidence in the level of agreement. In cases of disagreement, the research team revisited the relevant literature and discussed the most appropriate classification to achieve consensus. The nineteen OCM practices fell into six of the Agarwal and Ferratt categories (see Table 1).

Respondents were asked to select five OCM practices that they felt would be most useful to them. The limit of five tools was chosen to force respondents to make choices (rather than just ticking all the tools) while still giving them the option to indicate a variety of preferences. We also considered this to be more reflective of the real world than giving a rating (for example, on a 1-5 scale) to each OCM practice because people do not have time to participate in a large number of OCM interventions, even if available. Importantly, the list was presented in random order to each participant to avoid potential response bias (Dillman, 2007). Furthermore, each practice was briefly explained in a help menu. We added the number of OCM practices a respondent chose in each category, and used those totals as the dependent variables.

\section{Respondents}

Overall, 1,629 (42.7\%) respondents fully completed the career anchor and OCM measures, which is in line with response rates achieved in previous career anchor research in this area (Wils et al., 2010). The respondents and the organizations from which they were drawn are shown in Table 2. The respondents were predominantly male (85\%), married (54.0\%) and had no children (51.8\%). Their average age was 39.8 years (SD=8.82). Swiss citizens accounted for 861 (52.9\%) of respondents, with UK at 323 (19.8\%), Germany 233 (14.3\%), others 164 (10.1\%) and 48 (3.0\%) unknown. The Swiss respondents were very predominantly from the German-speaking areas of the country. Two thirds of these IT professionals (66.8\%) either held a Bachelor's, a Master's or a $\mathrm{PhD}$ degree, with a Bachelor's being the most frequent (32.2\%). The respondents worked in a wide range of IT functions, including consulting, business analysis, user support, security and 
quality management. The most widely represented IT functions were software development (27.9\%) and project management (14.4\%). Most of the respondents (86.4\%) worked full time, predominantly as permanent employees (94.7\%). We defined a respondent as a manager if they said their role was managerial and they reported having at least one direct report. On these criteria 411 (26.0\%) of respondents were managers. Respondents had worked in IT for an average of 13.6 years $(S D=8.26)$. They had been with their current employer for 8.53 years $(S D=7.75)$ and had held their current role for 3.44 years (SD=3.50). Comprehensive data on the IT workforces are sparse for the three main countries in this study. However, regarding gender, age and qualifications, our sample appears close to being representative because it did not show any significant demographic differences compared with the overall population of IT professionals in each country (E-Skills UK 2008; Zimmermann, 2005).

[Take in Table 2 near here]

\section{Analysis and results}

\section{Descriptive statistics}

Table 3 presents the descriptive statistics for career anchors. The anchors with the highest scores were lifestyle $($ mean $=3.92)$, job security $($ mean $=3.80)$ and service/dedication $($ mean $=3.75)$. At the lower end were entrepreneurial creativity (mean = 2.43), technical/functional competence $($ mean $=2.59)$ and managerial competence $($ mean $=2.75)$. These anchor scores are in line with previous research with IT professionals (Igbaria et al., 1999). Most of the correlations between anchor scores were highly statistically significant, but their overall magnitude was not high enough to cast doubt on the distinctiveness of any of the anchors. Similar to the confirmatory factor analysis results reported above, the median correlation (ignoring sign) was 0.15 , with the highest being 0.42 between managerial competence and entrepreneurial creativity and 0.33 between autonomy/independence and lifestyle, and between technical/functional competence and geographical security. 
[Take in Table 3 near here]

Details of the frequency of responses regarding OCM practices are provided in Table 4 and these are summarized in terms of the OCM categories in Table 5. It is striking that the three most frequently selected OCM practices constitute the technical employability training \& skill development category. Easily the most commonly endorsed OCM practice was on-the-job learning opportunities, which was chosen by 909 respondents (55.8\% of the total). Despite the relatively low mean score on the technical/functional career anchor, functional and technical skills training was the next most popular (731, 44.9\%). Personal development plans were just behind technical/functional skills training (700, 43.0\%). In general the seven OCM practices in the longer term business and leadership skill development category were not amongst the most frequently chosen. Interpersonal skills training (382, 23.4\%) was barely half as popular as functional and skills training. Opportunities to consider and reflect on one's career development were not often chosen on the whole (e.g. informal career discussions 333, 20.4\% and formal ones 261, 16.0\%), though career coaching (which was focused more on skill development) was somewhat more attractive (491, 30.1\%). Despite the career literature’s long-running love affair with mentoring, it was an OCM practice of choice for only 439 respondents.

[Take in Tables 4 and 5 near here]

The performance measurement and opportunities for advancement OCM categories were about equally popular overall. Regarding the former, performance appraisal and informal feedback were each selected by about one third of respondents, but formal feedback was much less popular, with fewer than one fifth of respondents opting for it. Regarding opportunities for advancement, all three practices in this category concerned clarity of organizational opportunity structures, with clear criteria for advancement being most commonly chosen (and the fourth most popular practice overall) by more than one third of respondents, and the other two by about one quarter. OCM practices in the work arrangements category were relatively rarely chosen. Outplacement was easily the least frequently endorsed technique (88, 5.4\%). Perhaps slightly 
more surprising given that the respondents were IT professionals, online networking/communities (the sole OCM practice in the sense of community category) was the second-least popular, with 146 endorsements (9.0\%).

\section{Associations between career anchors and preferences for OCM practices}

We used multiple linear regression analysis to test for associations between career anchor scores and preferences for OCM practices. In the case of sense of community, because there was only one OCM practice, and therefore scores could only be 0 or 1 , we used binary logistic regression (Cox, 1958). Then, working with the full sample (except for 48 cases where nationality was unknown, so $\mathrm{N}=1581$ ), we constructed a separate regression model for each of the six categories of OCM practices. In order to identify any systematic differences between nationalities in the relationships between career anchors and OCM practice preferences we then ran the same regression analyses for each of three nationalities separately: Swiss $(\mathrm{N}=858)$, UK $(\mathrm{N}=319)$, and German $(\mathrm{N}=233)$.

In step one of the analyses, control variables were force-entered into the regression model because previous research has shown their importance for career development (Biemann, Zacher, \& Feldman, 2012; Briscoe et al., 2012). For the full set of respondents these included age, gender, manager (vs not a manager), and nationality, for which we created dummy variables for UK, German and 'Other' citizens, so the Swiss respondents were the reference group. For the nationality-specific analyses, nationality was of course omitted from the control variables. We also included perceived availability of the relevant OCM practices as a control variable. This was because perceptions of usefulness might be affected by whether or not the respondent had access to and/or experience of a practice. In most areas the perceived availability of OCM practices lagged behind their percieved usefulness. The exception was the performance measurement category, where the availability of practices typically exceeded their perceived usefulness. 
Then in step 2 of the analyses we force-entered all the anchor scores into the equation. Therefore an anchor had to be related to an OCM practice independently of all other anchors and the control variables in order to register as significant.

Table 6 presents the results of these analyses. Each column of the table represents four regression analyses: first for all respondents, and then for Swiss, UK and German nationals separately. For the full sample, only significant standardized regression coefficients are shown. In these cases, the coefficients for each nationality are also shown, whether or not they were significant. The smaller numbers of respondents, especially for UK and Germany, mean that the regression coefficients may be the same as for the whole sample, but not significant. In such cases it would be misleading to conclude that there are differences between nationalities. Table 6 also shows significant results for specific nationalities even where there was not a significant result for the whole sample.

[Take in Table 6 about here]

First, we use the whole-sample analyses to address RQ1: How do individuals’ preferences for OCM practices vary with their career anchors? The lower part of Table 6 shows that collectively the career anchors accounted for highly statistically significant amounts of variance in preferences for OCM practices in five of the six OCM categories. The exception was the performance measurement category. Fifteen out of 54 (27.8\%) of possible relationships between anchors and OCM practice preferences were significant. This is highly significantly greater than one would expect by chance (single sample chi-square $=59.0, p<.001$ ). However, the proportions of variance explained in OCM practice preferences were typically quite small, not exceeding $5 \%$ of the total after control variables had been accounted for. Because of the range of control variables used, this is a rigorous test of the associations between career anchors and OCM practices.

The technical functional and managerial competence anchors behaved in opposite ways for the technical employability training and skill development and sense of community OCM 
practices. In both cases technical functional anchor scores were positively associated with choice of OCM practices in those categories, and managerial competence strongly negatively associated. On the other hand, the managerial competence anchor was strongly positively associated with selection of longer-term business and leadership skill development. Perhaps surprisingly, the technical functional anchor was not negatively associated with this OCM category (except for Swiss respondents), though it was negatively associated with the work arrangements category.

The job security anchor was positively associated with the opportunities for advancement OCM category, negatively with longer-term business and leadership skill development, and positively (just) with technical employability training and skill development. It might perhaps have been expected that job security would be negatively associated with the work arrangements category (outplacement and secondments) but this was not the case. However, this was the case for geographical security.

The service/dedication anchor was associated with less enthusiasm for the opportunities for advancement OCM practices and weakly positively associated with the longer-term business and leadership skill development ones. There was a near-significant negative association between the autonomy/independence anchor and the performance measurement OCM practices, and a positive association with being part of wider networks and communities.

The pure challenge anchor was associated in opposite directions with the two OCM categories that reflect personal development: negatively with longer-term business and leadership skill development, and weakly positively with technical skill development. Finally, neither the entrepreneurial creativity nor the lifestyle anchor showed any statistically significant associations with OCM practice preferences.

The control variables as a set explained statistically significant amounts of variance in all the OCM categories. Differences between nationality are discussed below. Apart from them, availability of OCM practices was positively associated with being selected as useful in three OCM categories, but not the other three. It therefore looks as if there was not a general 
'familiarity breeds liking' effect. There was a slight tendency for men to select OCM practices concerned with advancement more than women did, but they appeared not to be so enthusiastic about performance measurement.

\section{Differences between nationalities}

RQ2 asked What differences between nationalities exist in anchors, preferences for OCM practices and the associations between them? One way analysis of variance with Scheffe post hoc comparisons was conducted to test for differences between nationalities in the mean scores shown in Table 3. UK citizens scored significantly higher on managerial competence and job security (both $p<0.001$ ) than Swiss citizens. Swiss citizens scored higher than UK citizens on autonomy/independence $(p<0.01)$, geographical security $(p<0.01)$ and service/dedication $(p<$ 0.001). There was only one significant difference in anchor scores between UK and German citizens. UK citizens scored significantly lower on service/dedication $(p<0.001)$. The mean anchor scores for German and Swiss citizens were mostly similar but with two significant differences between them. German citizens scored higher on managerial competence $(p<0.05)$ but lower on geographical security $(p<0.01)$ than Swiss citizens.

There were some differences between nationalities in preferences for OCM practices, as indicated in Table 4. The UK respondents were markedly more likely than others to favor functional/technical skills training, but less likely to choose personal development plans. Both these OCM practices are in the technical employability training and skill development category. UK respondents were also the most likely to select clear description of career paths and job levels and (to a lesser extent) temporary jobs and assignments and outplacement, though in these latter cases it should be noted that the likelihood was still low. Differences between Swiss and German respondents were less marked, but the Swiss were somewhat more likely to select on-the-job learning opportunities, performance appraisal, personal development plans and career counseling. 
These differences were largely reflected in the regression analyses (see Table 6) where the dependent variables were OCM categories rather than practices, and we used dummy variables of UK, German and 'Other' citizens compared with Swiss citizens (as the reference group). The UK citizens tended to differ from the Swiss more than the other groups did. They were more likely to select OCM practices in the work arrangements and sense of community categories. They were less likely to select practices in the longer term business and leadership skill category. German citizens were marginally more interested in the opportunities for advancement practices. The 'Other' nationalities were more likely to select the sense of community practice (online networking and communities), probably because they were working away from their home country.

More subtle than differences between nationalities in anchors and OCM practices, are differences in the associations between anchors and OCM practice preferences. Table 6 shows significant associations for each nationality as well as the whole sample. The most robust findings in the sense that they were evident in the whole sample and at least two nationalities, were (i) the negative association between the technical/functional anchor and the work arrangements OCM practices; (ii) the tendency for managerial competence anchor scores to be positively associated with business and leadership development, and negatively associated with technical employability training and skill development; and (iii) the positive association of job security with opportunities for advancement and negative association with business and leadership skill development.

Several other relationships were consistent across nationalities in the sense that the regression coefficients were similar even though they did not reach significance in the smaller samples. Most notable here were the association between the technical functional anchor and technical employability training and skill development OCM practices, the negative association between managerial competence anchor scores and preference for online networking and 
community, and the tendency for scores on the service/dedication anchor to be associated with lower enthusiasm for opportunities for advancement OCM practices.

There were a few scattered significant associations between anchor scores and OCM practices that were evident in only one country. However, these were not prevalent (five in total) and they did not form a coherent pattern. There is some suggestion that for German respondents the technical employability training and skill development practices carried more connotations of being embedded in the organization than for other nationalities, and that for UK respondents the lifestyle anchor was a little more salient in determining preferences for OCM.

\section{Discussion}

The main objective of this study was to examine relationships between career anchors and how IT professionals enact their careers in the context of OCM. The secondary objective was to identify any differences between Swiss, UK and German IT professionals in their preferences for career anchors and organizational career management (OCM) practices, and in the relationships between these two domains. We found that there were indeed connections between career anchor scores and preferences for different types of OCM practice, and that these were more evident for some anchors and some OCM practices than for others. Although statistically highly significant in this large sample, most of these relationships explained only modest proportions of variance. Anchors and OCM practice preferences do not always line up together as one might expect. For example, despite the relatively low importance many of them placed on being a technical expert or a good manager, these IT professionals most often chose OCM practices to do with on-the-job development of key skills. There were some differences between nationalities in career anchor and OCM practice preferences. Taken as a whole, the results indicate that the UK and Swiss are substantially different from each other in several respects, whilst differences between each of those countries and Germany tended to be smaller and were less numerous. 
As shown in Table 6, the technical/functional, managerial competence and job security anchors accounted for most of the strongest significant effects regarding individuals’ perceived usefulness of OCM practices. OCM practice preferences of respondents with a strong technical functional anchor were in some respects the opposite of those with a strong managerial competence anchor. The same applies to the job security and service/dedication anchors. In line with Giles and West's (1995) results, these findings are important as they demonstrate that IT professionals have a range of career anchors and that understanding these anchors helps to predict the OCM practices IT professionals will find most useful. For example, although on-the-job learning opportunities and functional/technical skills training were overall the most commonly chosen OCM practices, they were less attractive to IT professionals with a high managerial competence anchor. These findings support those who have called for a more individualized approach to OCM (Jayasingam \& Yong, 2013; Chang et al., 2012; Jiang et al., 2001; Igbaria et al., 1999). Acknowledging inter-individual differences in organizations has been found to increase trust and commitment (Scholarios \& Marks, 2004), as well as to decrease turnover intentions (King et al., 2005). It may help reduce the 'grass is greener on the other side' effect and increase individual buy-in.

The 'specialist versus manager' dichotomy is helpful in understanding IT professionals' career needs, but it does not suffice (Tremblay, Wils, \& Proulx., 2002; Jiang et al., 2001). This is because several other anchors are more important to many IT professionals, and because those anchors in some cases associate with preferred OCM practices. For example, the importance of the need to contribute to a collective cause they value (the service/dedication anchor) and job security have significant and somewhat contrasting implications for the provision of OCM practices. Those with a strong job security anchor are more likely to respond positively to OCM practices that support opportunities for advancement.

Our findings shed further light on how anchors manifest in career development. Whilst some of these are in line with what one would expect from the content of the anchor, there are a 
few possible surprises, which may be a result of changes in the labor market since the anchor concept was developed (Schein \& Van Maanen, 2016). The managerial competence anchor might have been expected to be positively associated with opportunities for advancement OCM practices (Gubler et al., 2015), but it was not. The managerial competence anchor seems to manifest in a single-minded development of transferable managerial skills, often through face to face interaction, rather than engagement with the organization, or indeed with the wider online professional community. This may be an example of the changes in anchors since the 1970s suggested by Schein and Van Maanen (2016). Conversely, the job security anchor was associated with preference for opportunities for advancement OCM practices. This is no doubt partly due to the emphasis on clarity in the OCM practices in this category, but it also signals that the job security anchor should not be taken to mean a lack of interest in progression in an organization, thus supporting Clarke’s (2012) call for a redefinition of the 'organizational career'. It is surprising that the job security anchor was not negatively associated with the work arrangements OCM category because the two OCM practices in that category signal instability and uncertainty - but then again, they also signal that the organization is doing its best to find a role for the person. Conversely, the technical functional anchor shows clear signs of a desire for stability and certainty, and engagement with a professional community. This goes somewhat beyond its original meaning (Schein, 1978).

Our findings suggest that the ways in which individuals perceive OCM practices may be affected by individuals' nationality. This supports arguments that careers and their development are highly contextualized (e.g. Briscoe et al., 2012; Gerber et al., 2009; Khapova et al., 2009). Nevertheless, this study provides little evidence that the models of management careers discussed by Davoine and Ravasi (2013) find expression in OCM practice preferences. UK citizens did not place stronger emphasis on OCM practices concerned with performance assessment, and German citizens did not especially favor training and development. Our findings here are somewhat more in line with Gerber and colleagues (2009) and Magun et al. (2016). UK citizens were more 
concerned than Swiss about job security and managerial competence (though interestingly not about training and development relevant to management) whilst the Swiss showed more emphasis on personal growth and contribution to the greater good. However, the lower centrality of work for UK respondents found by Gerber and colleagues did not show up in higher scores on the lifestyle anchor. Consistent with Magun et al. (2016), Germany tended to be in between UK and Switzerland, and not often significantly different from either (recall however that the Swiss respondents were predominantly from the culturally and linguistically German part of Switzerland). By far the biggest differences between nationalities in selection of OCM practices (see Table 4) were that the UK citizens were much more likely than Swiss or German to select functional/technical skills training and clear description of career paths and job levels. This is consistent with wanting clarity and conventionality, which is part of Magun et al.’s (2016) notion of 'weak social focus', and it corresponds to Gerpott et al.'s (1988) findings of strong technical anchors among UK engineers.

Our findings also contribute to the study and the management of careers in organizations. Existing classifications of OCM practices (Lewis \& Arnold, 2012; Agarwal \& Ferratt, 2002; 1999; Baruch \& Peiperl, 2000) have been brought together and grouped in a new way that uses insights from both the HR and IT-related literatures. The six categories we use may offer a useful set of headings under which to consider and classify organizational career management activities, based primarily on their purpose rather than more abstract properties (c.f. Hirsh \& Jackson, 2004). Using the categorization of OCM practices offered here and the relationships identified between them and career anchor scores may help both researchers and practitioners to consider OCM in a more coherent and considered way than hitherto.

\section{Limitations, practical implications, and future research}

The findings of this study have provided insights regarding career anchors, OCM practices, connections between them, and differences and similarities between three European nationalities. 
However, the study is subject to a number of limitations. When selecting OCM practices, participants were limited to selecting a maximum of five practices that they felt would be useful to them. We were wary of respondents responding fairly uniformly positively to the OCM practices, nearly all of which would likely be considered 'nice to have' by almost everyone. We also wanted to face respondents with the cognitive task of considering the OCMs as a group and making choices that would hopefully reflect what they would (or do) prioritise in their workplace. However, we acknowledge that some participants may have considered an even wider range of practices to be potentially useful and that the quality of the practices may have varied in each organization.

We acknowledge that the number of OCM practices available in each category varied substantially. For instance, the category 'work arrangements' contained two practices, whereas 'Longer term business and leadership skill development' contained seven. Thus, the possible numbers of responses in each category varied, and therefore mean levels were not the same. To address this variation, the regression analyses used standardized scores within the observed distribution for each variable, so the regression coefficients were comparable. However, the bigger OCM categories may have had more fidelity of measurement because they allow more chances to express preferences. Also, there was an ipsative element to the measurement because if a person made several choices in one OCM category there were fewer left for other categories. Thus, strictly speaking, the dependent variables were not entirely statistically independent of each other. However, this did not affect the expected magnitude of regression coefficients.

The majority of participants in this study were from three countries: Switzerland, Germany and the United Kingdom. Although this approach enables us to generalize our findings across cultures and labor markets to some extent, we cannot say anything beyond these countries. Further, the Swiss respondents were predominantly from the German part of Switzerland, which may have limited the cultural diversity available. Several of the participating organizations were 
located entirely or predominantly in one country and mainly employed the nationals of that country, so there is the potential for confounding of organization and nationality. Finally, although we have argued that IT professionals are likely to respond similarly to other professionals such as accountants and engineers, we cannot be sure of that. Our data are extensive, multi-organizational and multi-national, all of which help generalizability, but they are from one profession only, albeit many different aspects of it.

Our findings have some practical implications for HR managers. First, in general, professionals are most interested in OCM that promotes their competence in their job in the present and the near future. Second, this seems to be the case even though being a technical specialist is not the top priority for many professionals. Third, take-up of career interventions that relate to longer-term and broader career paths and skill development, and the development of professional communities of practice is likely to be somewhat lower, so if they are deemed to be important it will be vital to promote them vigorously. Fourth, awareness of the preferred career anchors of professional staff can help to inform decisions about the organizational career management to offer. For example, managerially-orientated staff are more likely than others to be interested not only in non-technical skills training, but also in activities that combine the interpersonal and the reflective, such as career coaching. Also, professionals oriented towards job security are interested not only in their present job but also in the prospects of advancement in a well-defined structure. Fifth, the career anchor scores suggest that professionals tend to be highly concerned with their non-work life and with job security, so HR interventions that can be seen to protect these (such as technical training and flexible hours) are likely to be especially welcome. Sixth, relative to Swiss and German colleagues, UK professionals are likely to be (even) more concerned with their job security, clarity of career paths, and technical skills, and less orientated towards service and development of broader managerial skills. In other words, their attention is relatively narrow and self-focused. 
Future research could seek to replicate and/or extend these findings, perhaps with different populations. The obvious extension would be to different occupational groups. Extension could also mean exploring ways in which career anchors link with career selfmanagement activities (King, 2004) such as networking behaviors, career goal-setting, and career exploration. For example, the pure challenge anchor might be associated with a strong focus on goal-setting, whilst the reverse might be the case for the lifestyle anchor. It would also be instructive to understand more about the reasons for individuals’ preferences for OCM practices. Like most quantitative studies, our research establishes statistical relationships between variables and presents rationales for them, but we do not know whether these rationales accord with how the people concerned experience it. One way of investigating this would be to ask people with particularly clear anchor preferences to talk through their reasoning for why they selected the OCM practices that they did, and examine whether those explanations reflect (i) the description of their most dominant career anchor and (ii) the arguments put forward in this and other literature.

\section{Acknowledgement}

We would like to thank Professor Bondarouk and the review team for all the constructive comments and suggestions that were most helpful in revising the paper and in offering a stronger contribution. 


\section{References}

Abele, A. E., \& Wiese, B. S. (2008). The nomological network of self management strategies and career success. Journal of Occupational and Organizational Psychology, 81(4), 733749.

Agarwal, R., \& Ferratt, T. W. (1999). Coping with labor scarcity in Information Technology: Strategies and practices for effective recruitment and retention. Cincinnati: Pinnaflex Press.

Agarwal, R., \& Ferratt. T. W. (2002). Enduring practices for managing IT professionals. Communications of the ACM, 45(9), 73-79.

Agarwal, R., De, P., \& Ferratt, T. W. (2002). Explaining an IT professional's preferred employment duration: empirical tests of a causal model of antecedents. Paper presented at the ACM SIGCPR Conference, Kristiansand, Norway.

Arbuckle, J. (2014). IBM SPSS AMOS 23 users’ guide. New York: IBM \&Amos Development Corporation.

Arnold, J. (1997). Managing careers into the 21st century. London: Paul Chapman Publishing.

Arthur, M. B., \& Rousseau, D. M. (1996) (Eds). The boundaryless career. Oxford University Press.

Baruch, Y. (2004). Managing careers: Theory and practice. Harlow: Pearson Education.

Baruch, Y., \& Peiperl, M. (2000). Career management practices: An empirical survey and implications. Human Resource Management, 39(4), 347-366.

Biemann, T., Zacher, H., \& Feldman, D. C. (2012). Career patterns: A twenty-year panel study. Journal of Vocational Behavior, 81(2), 159-170. doi: 10.1016/j.jvb.2012.06.003

Brewster, C., \& Mayrhofer, W. (Eds.) (2012). Handbook of research on comparative human resource management. Cheltenham: Edward Elgar.

Briscoe, J. P., Hall, D. T., \& Mayrhofer, W. (Eds.) (2012). Careers around the world: Individual and contextual perspectives. New York: Routledge.

Browne, M. W., \& Cudeck, R. (1989). Single sample cross-validation indices for covariance structures. Multivariate Behavioral Research, 24(4), 445-455.

Byrne, B. M. (1994). Structural equation modeling with EQS and EQS/Windows: Basic concepts, applications, and programming. London: Sage.

Chang, C. L. H. (2010). The study of the turnover of MIS professionals - the gap between Taiwanese and US societies. International Journal of Information Management, 30(4), 301-314. 
Chang, C. L. H., Chen, V., Klein, G., \& Jiang, J. J. (2011). Information system personnel career anchor changes leading to career changes. European Journal of Information Systems, 20, 103-117.

Chang, C. L. H., Jiang, J. J., Klein, G., \& Chen, H. G. (2012). Career anchors and disturbances in job turnover decisions - a case study of IT professionals in Taiwan. Information \& Management, 49(6), 309-319.

Chudzikowski, K., Demel, B., Mayrhofer, W., Briscoe, J. P., Unite, J., Bogićević Milikić, B., Hall, D. T., Heras, M. L., Shen, Y., \& Zikic, J. (2009). Career transitions and their causes: a country-comparative perspective. Journal of Occupational and Organizational Psychology, 82(4), 825-849.

Clarke, M. (2012). The organizational career: Not dead but in need of redefinition. The International Journal of Human Resource Management, 24(4), 684-703. doi: 10.1080/09585192.2012.697475

Coetzee, M., Schreuder, D., \& Tladinyane, R. T. (2014). Employees’ work engagement and job commitment: The moderating role of career anchors. Journal of Human Resource Management, 12(1), 1-12.

Cox, D. R. (1958). The regression analysis of binary sequences. Journal of the Royal Statistical Society. Series B (Methodological), 215-242.

Crawshaw, J.R. \& Game, A. (2015). The role of line managers in employee career management: an attachment theory perspective. The International Journal of Human Resource Management, 26(9), 1182-1203.

Crook, C. W., \& Crepeau, R. G. (1997). A study of career orientations of information system students and professionals. Communications of the ACM, 138-144.

Danziger, N., Rachman-Moore, D., \& Valency, R. (2008). The construct validity of Schein's career anchors orientation inventory. Career Development International, 13(1), 7-19.

Davoine, E., \& Ravasi, C. (2013). The relative stability of national career patterns in European top management careers in the age of globalisation: A comparative study in France/Germany/ Great Britain and Switzerland. European Management Journal, 31(2), 152-163.

De Vos, A., \& Dries, N. (2013). Applying a talent management lens to career management: The role of human capital composition and continuity. The International Journal of Human Resource Management, 24(9), 1816-1831. 
Derr, C. B., \& Laurent, A. (1989). The internal and external career: A theoretical and crosscultural perspective. In M. B. Arthur, D. T. Hall, B. S. Lawrence (Eds) Handbook of career theory. Pp. 454-471. Cambridge: Cambridge University Press

Dillman, D. A. (2007). Mail and internet surveys. Hoboken N. J., USA: John Wiley.

Doyle, M. (2000). Managing careers in organizations. In A. Collin, \& W. Patton (Eds), The future of career (pp. 228-242). Cambridge, UK: Cambridge University Press.

E-Skills, UK. (2008). Technology counts: IT and telecoms insights 2008. London: E-Skills UK.

Feldman, D. C., \& Bolino, M. C. (1996). Careers within careers: reconceptualizing the nature of career anchors and their consequences. Human Resource Management Review, 6(2), 89112.

Ferratt, T. W., \& Short, L. E. (1986). Are information systems people different? An investigation of motivational differences. MIS Quarterly, 21, 377-387.

Ferratt T. W., Agarwal R., Brown C. V., \& Moore J. E. (2005). IT human resource management configurations and IT turnover: theoretical synthesis and empirical analysis. Information Systems Research, 16(3), 237-255.

Fleiss, J. L. (1971). Measuring nominal scale agreement among many raters. Psychological Bulletin, 76, 378-382.

Gerber, M., Wittekind, A., Grote, G., Conway, N., \& Guest, D. (2009). Generalizability of career orientations: A comparative study in Switzerland and Great Britain. Journal of Occupational and Organizational Psychology, 82(4), 779-801.

Gerpott, T. J., Domsch, M., \& Keller, R. T. (1988). Career orientations in different countries and companies: An empirical investigation of West German, British and US industrial R\&D professionals. Journal of Management Studies, 25(5), 439-462.

Giles, M., \& West, M. (1995). People as sculptors versus sculptures: What shape career development programmes. Journal of Management Development, 14(10), 48-63. doi: 10.1108/02621719510100834.

Greenhaus, J. H., Callanan, G. A., \& Godshalk, V. M. (2009). Career Management. London: Sage.

Guan, Y., Wen, Y., Chen, S. X., Liu, H., Si, W., Liu, Y. (2014). When do salary and job level predict career satisfaction and turnover intention among Chinese managers? The role of perceived organizational career management and career anchor. European Journal of Work and Organizational Psychology, 23(4), 596-607. 
Gubler, M., Arnold, J., \& Coombs, C. (2014). Reassessing the protean career concept: Empirical findings, conceptual components, and measurement. Journal of Organizational Behavior, 35(S1), S23-S40.

Gubler, M., Biemann, T., Tschopp, C., \& Grote, G. (2015). How career anchors differentiate managerial career trajectories: A sequence analysis perspective. Journal of Career Development, 42(5), 412-430.

Hall, D. T. (2002). Careers in and out of organizations. London: Sage.

Hall, D. T., Briscoe, J. P., Dickmann, M., \& Mayrhofer, W. (2012). Implications for the management of people and organizations. In J. P. Briscoe, D. T. Hall \& W. Mayrhofer (Eds.), Careers around the world: Individual and contextual perspectives (pp. 166-186). New York: Routledge.

Hirsh, W., \& Jackson, C. (2004). Managing careers in large organizations. London: The Work Foundation.

Hofstede, G. (2001). Culture's consequences. ( $2^{\text {nd }}$ Ed). London: Sage.

Hsu, M. K., Chen, H. G., Jiang, J. J., \& Klein, G. (2003). Career satisfaction for managerial and technical anchored IS personnel in later career stages. The Data Base for Advances in Information Systems, 34(4), 64-72.

Igbaria, M. \& Baroudi, J. J. (1993). A short-form measure of career orientations: a psychometric evaluation. Journal of Management Information Systems, 10(2), 131-154.

Igbaria, M., Kassicieh, S. K., \& Silver, M. (1999). Career orientations and career success among research, development and engineering professionals. Journal of Engineering and Technology Management, 16(1), 29-54.

Igbaria, M., Meredith, G., \& Smith, D. C. (1995). Career orientations of information systems employees in South Africa. Journal of Strategic Information Systems, 4(4), 319-340.

Igbaria, M. \& Weaver McCloskey, D. (1996). Career orientations of MIS employees in Taiwan. ACM SIGCPR Computer Personnel, 17(2), 3-24.

Inkson, K., Dries, N., \& Arnold, J. (2014). Understanding Careers: Metaphors of working lives. $2^{\text {nd }}$ Ed. London: Sage.

Ituma, A., \& Simpson, R. (2007). Moving beyond Schein's typology: Individual career anchors in the context of Nigeria. Personnel Review, 36(6), 978-995.

Jayasingam, S. \& Yong, J.R., (2013). Affective commitment among knowledge workers: the role of pay satisfaction and organization career management. The International Journal of Human Resource Management, 24(20), 3903-3920. 
Jiang, J. J., Klein, G., \& Balloun, J. L. (1995). The diverse career orientations of MIS personnel. Computer Personnel, 16(4), 3-14.

Jiang, J. J., Klein, G., \& Balloun, J. L. (2001). The joint impact of internal and external career anchors on entry-level IS career satisfaction. Information \& Management, 39, 31-39.

Joseph, D., Boh, W. F., Soon, A., \& Slaughter, S. (2012). The career paths less (or more) traveled: a sequence analysis of IT career histories, mobility patterns, and career success. MIS Quarterly, 36(2), 427-452.

Kaiser, K. M., \& Bostrom, R. P. (1982). Personality characteristics of MIS project teams: An empirical study and action-research design. MIS Quarterly, 6, 43-60.

Khapova, S. N., Vinkenburg, C. J., \& Arnold, J. (2009). Careers research in Europe: Identity and contribution. Journal of Occupational and Organizational Psychology, 82(4), 709-719.

King, Z. (2004). Career self-management: Its nature, causes and consequences. Journal of Vocational Behavior, 65(1), 112-133.

Lacity, M.C., Iyer, V. V., \& Rudramuniyaiah, P.S., (2008). Turnover intentions of Indian IS professionals. Information Systems Frontiers, 10(2), 225-241.

Lazarova, M., Cerdin, J.-L., \& Liao, Y. (2014). The internationalism career anchor. International Studies of Management \& Organization, 44(2), 9-33.

Lewis, S., \& Arnold, J. (2012). Organizational career management in the UK retail buying and merchandising community. International Journal of Retail \& Distribution Management, 40(6), 451-470.

Lips Wiersma, M., \& Hall, D. T. (2007). Organizational career development is not dead: A case study on managing the new career during organizational change. Journal of Organizational Behavior, 28(6), 771-792.

Magun, V., Rudnev, M., \& Schmidt, P. (2016). Within- and between-country value diversity in Europe: A typological approach. European Sociological Review, 32(2), 189-202.

Martineau, Y., Wils, T., \& Tremblay, M. (2005). La multiplicité des ancres de carrière chez les ingénieurs québécois - Impacts sur les cheminements et le succès de carrière. Relations Industrielles/Industrial Relations, 60(3), 455-482.

Mgaya, K.V., Uzoka, F.M., Kitindi, E.G., \& Shemi, A.P. (2009). Examining career orientations of information systems personnel in an emerging economy context. Proceedings of the 2009 ACM SIGCPR conference on computer personnel research, pp. 41-56, Limerick, Ireland. 
Mignonac, K., \& Herrbach, O. (2003). Managing individual career aspirations and corporate needs: A study of software engineers in France. Journal of Engineering and Technology Management, 20(3), 205-230.

Nordvik, H. (1996). Relationships between Holland's vocational typology, Schein's career anchors and Myers-Briggs' types. Journal of Occupational and Organizational Psychology, 69(3), 263-275.

Quesenberry, J. L., \& Trauth, E. M. (2012). The (dis)placement of women in the IT workforce: An investigation of individual career values and organisational interventions. Information Systems Journal, 22(6), 457-473.

Reich, B. H., \& Kaarst-Brown, M. L. (1999). Seeding the line: Understanding the transition from IT to non-IT careers. MIS Quarterly, 23(3), 337-364.

Rodrigues, R., Guest, D., \& Budjanovcanin, A. (2013). From anchors to orientations: Towards a contemporary theory of career preferences. Journal of Vocational Behavior, 83(2), 142152.

Sarchielli, G., \& Toderi, S. (2007). Le àncore di carriera: motivi di interesse, opportunità di ricerca e contributo alla validazione italiana del Career Orientation Inventory (COI-it). Bollettino di Psicologia Applicata, 54(252), 21-32.

Schein, E. H., (1978) Career dynamics: Matching individual and organizational needs. Reading, USA: Addison-Wesley Publishing Company.

Schein, E. H. (1984). Culture as an environmental context for careers. Journal of Occupational Behavior, 5(1), 71-81. doi: 10.1002/job.4030050107.

Schein, E. H., (1990). Career anchors: Discovering your real values. San Diego: University Associates.

Schein, E. H., (1996). Career anchors revisited: implications for career development in the 21st century. Academy of Management Executive, 10(4), 80-88.

Schein, E. H., \& Van Maanen, J. (2016). Career anchors and job/role planning: Tools for career and talent management. Organizational Dynamics, in press, doi: 10.1016/j.orgdyn.2016.07.002

Scholarios, D., Van Der Heijden, B. I. J. M., Van Der Schoot, E., Bozionelos, N., Epitropaki, O., Jedrzejowicz, P., Knauthf, P., Marzecg, I., Mikkelsenh, A., \& Van Der Heijdeb, C. M., (2008). Employability and the psychological contract in European ICT sector SMEs. International Journal of Human Resource Management, 19(6), 1035-1055.

Schwartz, S. H. (2008). Cultural value orientations: Nature and implications of national differences. Moscow: State University - Higher School of Economics Press. 
Shen, Y., Demel, B., Unite, J., Briscoe, J. P., Hall, D. T., Chudzikowski, K., ... \& Fei, Z. (2015).

Career success across 11 countries: implications for international human resource management. The International Journal of Human Resource Management, 26(13), 17531778.

Smith-Ruig, T. (2008). Making sense of careers through the lens of a path metaphor. Career Development International, 13(1), 20-32.

Sturges, J., Conway, N. \& Liefooghe, A., (2008). What's the deal? An exploration of career management behaviour in Iceland. The International Journal of Human Resource Management, 19(4), 752-768.

Sturges, J., Guest, D., Conway, N., \& Mackenzie Davey, K., (2002). A longitudinal study of the relationship between career management and organizational commitment among graduates in the first ten years at work. Journal of Organizational Behavior, 23(6), 731748.

Sullivan, S. E., \& Baruch, Y. (2009). Advances in career theory and research: A critical review and agenda for future exploration. Journal of Management, 35(6), 1542-1571.

Super, D. E. (1953). A theory of vocational development. American Psychologist, 8(5), 185-190.

Suutari, V., \& Taka, M. (2004). Career anchors of managers with global careers. Journal of Management Development, 23(9), 833-847.

Tremblay, M., Wils, T., \& Proulx, C., (2002). Determinants of career path preferences among Canadian Engineers. Journal of Engineering and Technology Management, 19(1), 1-23.

Wils, L., Wils, T., \& Tremblay, M. (2010). Toward a career anchor structure: An empirical investigation of engineers. Relations Industrielles/Industrial Relations, 65(2), 236-256.

Wrzesniewski, A., \& Dutton, J. E. (2001). Crafting a job: Revisioning employees as active crafters of their work. Academy of Management Review, 26(2), 179-201.

Wynne, L. A., Ferratt, T. W., \& Biros, D. P. (2002). Career anchors of United States Air Force information systems workers: a turnover predictor? Paper presented at the ACM SIGCPR Conference, Kristiansand, Norway.

Yarnall, J. (1998). Career anchors: Results of an organisational study in the UK. Career Development International, 3(2), 56-61.

Yarnall, J. (2008). Strategic career management. Oxford: Butterworth-Heinneman.

Zikic, J., \& Hall, D. T. (2009). Toward a more complex view of career exploration. The Career Development Quarterly, 58(2), 181-191.

Zimmermann, J., (2005). Warum braucht die informatik mehr frauen? Professional Computing, 1, 34-36. 
Table 1. Organizational career management practices selected for this study

\begin{tabular}{|c|c|c|c|c|}
\hline \multicolumn{2}{|c|}{ General HRM } & \multirow{2}{*}{$\begin{array}{c}\text { IT HRM } \\
\text { Agarwal and Ferratt }(1999 ; 2002)\end{array}$} & \multirow[t]{2}{*}{ OCM practices selected } & \multirow{2}{*}{$\begin{array}{l}\text { OCM category } \\
\text { Agarwal and Ferratt (1999) }\end{array}$} \\
\hline Baruch and Peiperl (2000) & $\begin{array}{l}\text { Lewis and Arnold } \\
\text { (2012) }\end{array}$ & & & \\
\hline Formal education & $\begin{array}{l}\text { Training and } \\
\text { educational } \\
\text { opportunities }\end{array}$ & $\begin{array}{l}\text { In-house or other formal training } \\
\text { program }\end{array}$ & $\begin{array}{l}\text { 1) Functional/ technical skills training } \\
\text { 2) On-the-job learning opportunities }\end{array}$ & $\begin{array}{l}\text { Technical employability } \\
\text { training and skill } \\
\text { development }\end{array}$ \\
\hline $\begin{array}{l}\text { Written personal career } \\
\text { planning }\end{array}$ & $\begin{array}{l}\text { Personal development } \\
\text { plans (PDP) }\end{array}$ & $\begin{array}{l}\text { Development plans and } \\
\text { competency/skill based training }\end{array}$ & 3) Personal development plan & \\
\hline $\begin{array}{l}\text { Career counseling by the } \\
\text { direct supervisor }\end{array}$ & $\begin{array}{l}\text { Career counseling with } \\
\text { line manager }\end{array}$ & e & $\begin{array}{l}\text { 4) Career coaching } \\
\text { 5) Formal career discussions } \\
\text { 6) Informal career discussions }\end{array}$ & $\begin{array}{l}\text { Longer term business and } \\
\text { leadership skill } \\
\text { development }\end{array}$ \\
\hline $\begin{array}{l}\text { Career counseling by the } \\
\text { HR department }\end{array}$ & $\begin{array}{l}\text { Specialized career } \\
\text { counseling }\end{array}$ & - & 7) Career counseling & \\
\hline Formal mentoring & Mentoring program & $\begin{array}{l}\text { Individual or mentor-based } \\
\text { development }\end{array}$ & 8) Mentoring program & \\
\hline Career workshops & $\begin{array}{l}\text { Career planning } \\
\text { workshops }\end{array}$ & $\begin{array}{l}\text { Career planning } \\
\text { Building business /leadership skills }\end{array}$ & $\begin{array}{l}\text { 9) Career workshops } \\
\text { 10) Interpersonal skills training }\end{array}$ & \\
\hline Dual career ladder & Career paths/job maps & Promotion from within career paths & $\begin{array}{l}\text { 11) Clear criteria for advancement } \\
\text { 12) Clear description of career paths } \\
\text { and job levels } \\
\text { 13) Transparent internal job market }\end{array}$ & $\begin{array}{l}\text { Opportunities for } \\
\text { advancement }\end{array}$ \\
\hline $\begin{array}{l}\text { Performance appraisal as } \\
\text { a basis for career planning }\end{array}$ & $\begin{array}{l}\text { Performance appraisal } \\
\text { for career planning }\end{array}$ & $\begin{array}{l}\text { Annual ‘traditional’ performance } \\
\text { appraisal } \\
\text { More frequent appraisals }\end{array}$ & $\begin{array}{l}\text { 14) Formal feedback } \\
\text { 15) Informal feedback }\end{array}$ & Performance measurement \\
\hline $\begin{array}{l}\text { Peer appraisal } \\
\text { Upward appraisal }\end{array}$ & 360-degree appraisal & 360-degree performance appraisal & 16) Performance appraisal & \\
\hline- & - & $\begin{array}{l}\text { Communication by senior } \\
\text { management } \\
\text { Social and socially responsible } \\
\text { activities, Intranets, newsletters }\end{array}$ & 17) Online networking /communities & Sense of community \\
\hline Lateral moves & $\begin{array}{l}\text { Job assignment } \\
\text { Secondment }\end{array}$ & $\begin{array}{l}\text { Job rotation, interesting work } \\
\text { Teams } \\
\text { Redesign of work-space }\end{array}$ & $\begin{array}{l}\text { 18) Outplacement } \\
\text { 19) Temporary assignment } \\
\text { /secondments }\end{array}$ & Work arrangements \\
\hline
\end{tabular}


Table 2. Profiles of participating organizations and response rates

\begin{tabular}{|c|c|c|c|c|c|c|}
\hline & Business area & Sector & Location & Sample population & Responses & Response rate \\
\hline Org01 & Software development & Private sector & Switzerland & 95 & 58 & $61 \%$ \\
\hline Org02 & Governmental IT provider & Public sector & Switzerland & 873 & 223 & $26 \%$ \\
\hline Org03 & Energy industry & Private sector & United Kingdom & 469 & 242 & $52 \%$ \\
\hline Org04 & Software development & Private sector & Switzerland & 85 & 65 & $76 \%$ \\
\hline Org05 & Car manufacturing & Private sector & $\begin{array}{l}\text { Germany and United } \\
\text { Kingdom }\end{array}$ & 620 & 207 & $33 \%$ \\
\hline Org06 & Software development & Private sector & Switzerland & 14 & 14 & $100 \%$ \\
\hline Org07 & Telecommunications & Private sector & Switzerland & 500 & 118 & $24 \%$ \\
\hline Org08 & Networking services & Public sector & Switzerland & 83 & 59 & $71 \%$ \\
\hline Org09 & Financial services & Private sector & Switzerland & 865 & 528 & $61 \%$ \\
\hline Org10 & $\begin{array}{l}\text { Software development and } \\
\text { consulting }\end{array}$ & Private sector & $\begin{array}{l}\text { Switzerland, Germany and } \\
\text { United Kingdom }\end{array}$ & 213 & 115 & $54 \%$ \\
\hline Totals & & & & 3,817 & 1,629 & $43 \%$ \\
\hline
\end{tabular}

Note: With the exception of Org07, all organizations agreed to send out the survey to their entire IT workforce. Org07 only wanted to contact 500 IT employees.

These were selected at random from the total IT workforce of 1,376. 
Table 3. Means, standard deviations and intercorrelations between career anchors

\begin{tabular}{|c|c|c|c|c|c|c|c|c|c|c|}
\hline & & & Career Ancl & & & & & & & \\
\hline & $\begin{array}{c}\text { Mean } \\
\text { Swiss/UK/Ger }\end{array}$ & $\begin{array}{c}\text { SD } \\
\text { Swiss/UK/Ger } \\
\end{array}$ & $\begin{array}{l}\text { Technical } \\
\text { /Functional }\end{array}$ & $\begin{array}{l}\text { Managerial } \\
\text { Competence }\end{array}$ & $\begin{array}{l}\text { Geographical } \\
\text { Security }\end{array}$ & $\begin{array}{l}\text { Job } \\
\text { Security }\end{array}$ & $\begin{array}{l}\text { Entrepreneurial } \\
\text { Creativity }\end{array}$ & $\begin{array}{l}\text { Autonomy/ } \\
\text { Independence }\end{array}$ & $\begin{array}{l}\text { Service/ } \\
\text { Dedication }\end{array}$ & $\begin{array}{l}\text { Pure } \\
\text { Challenge }\end{array}$ \\
\hline Technical / & 2.59 & 0.81 & & & & & & & & \\
\hline Functional & 2.562 .662 .50 & 0.790 .840 .79 & & & & & & & & \\
\hline Managerial & 2.75 & 1.02 & $10 * *$ & & & & & & & \\
\hline Competence & 2.602 .952 .80 & 0.951 .090 .98 & $-0.19{ }^{\prime \prime}$ & & & & & & & \\
\hline Geographical & 2.98 & 1.09 & $033 * *$ & $-025 * *$ & & & & & & \\
\hline Security & 3.102 .852 .80 & 1.081 .151 .05 & 0.0 & -0.25 & & & & & & \\
\hline Joh Security & 3.80 & 0.81 & $024 * *$ & 002 & $022 * *$ & & & & & \\
\hline - & 3.733 .983 .78 & 0.780 .820 .82 & 0.24 & 0.02 & 0.22 & & & & & \\
\hline Entrepreneurial & 2.43 & 1.09 & $-011 * *$ & $042 * *$ & $-021 * *$ & $-020 * *$ & & & & \\
\hline Creativity & 2.352 .532 .36 & 1.081 .101 .07 & -0.11 & 0.72 & -0.21 & -0.20 & & & & \\
\hline Autonomy/ & 3.38 & 0.74 & $0 \cap 8 * *$ & ר & 004 & 001 & $010 * *$ & & & \\
\hline Independence & 3.443 .263 .36 & 0.730 .780 .74 & 0.08 & -0.02 & 0.04 & -0.01 & $0.19^{n}$ & & & \\
\hline Service/ & 3.75 & 0.79 & 000 & $015 * *$ & 004 & $015 * *$ & $015 * *$ & $013 * *$ & & \\
\hline Dedication & 3.843 .423 .85 & 0.700 .960 .70 & & & . & . & . & 0.05 & & \\
\hline Pure Challenoe & 3.29 & 0.74 & $006 *$ & $026 * *$ & $011 * *$ & $0 \cap 9 * *$ & $023 * *$ & $010 * *$ & $0 ? 2 * *$ & \\
\hline P une Cildnenge & 3.253 .333 .37 & 0.730 .790 .70 & 0.00 & 0.20 & -0.11 & -0.05 & 0.25 & 0.15 & 0.24 & \\
\hline I ifestvle & 3.92 & 0.68 & $010 * *$ & $0>1 * *$ & $077 * *$ & $016 * *$ & $000 * *$ & $032 * *$ & $008 * *$ & 001 \\
\hline Lilestyic & 3.903 .943 .94 & 0.680 .700 .68 & 0.10 & -0.21 & $0.2<$ & 0.10 & -0.00 & 0.05 & 0.00 & -0.04 \\
\hline
\end{tabular}

*** significant ( $p=0.001$ level two-tailed); ${ }^{* *}$ significant at the $\left(p=0.01\right.$ level two-tailed); ${ }^{*}$ significant $(p=0.05$ level two-tailed $)$ 
Table 4. Organizational career management practice frequencies

\begin{tabular}{|c|c|c|c|c|c|}
\hline Organizational career management practice (category) & $\begin{array}{l}\% \text { Practice } \\
\text { useful (Whole } \\
\text { sample, } \\
\mathrm{N}=1629 \text { ) }\end{array}$ & $\begin{array}{l}\text { \% Practice } \\
\text { useful } \\
\text { (Swiss, } \\
\mathrm{N}=861 \text { ) }\end{array}$ & $\begin{array}{l}\text { \% Practice } \\
\text { useful } \\
\text { (UK, } \\
\mathrm{N}=323 \text { ) }\end{array}$ & $\begin{array}{l}\text { \% Practice } \\
\text { useful } \\
\text { (German, } \\
\mathrm{N}=233 \text { ) }\end{array}$ & $\begin{array}{l}\text { Differences } \\
\text { between } \\
\text { nationalities } \\
\text { (Chi-Square) }\end{array}$ \\
\hline $\begin{array}{l}\text { On-the-job learning opportunities (Technical employability training \& skill development) } \\
\text { (e.g. opportunity to develop new skills through active participation in a new project) }\end{array}$ & 55.8 & 57.5 & 57.0 & 47.6 & $7.47^{*}$ \\
\hline $\begin{array}{l}\text { Functional/technical skills training (Technical employability training \& skill development) } \\
\text { (e.g. course on a programming language or a hardware component) }\end{array}$ & 44.9 & 38.8 & 60.1 & 41.2 & $44.0 * * *$ \\
\hline $\begin{array}{l}\text { Clear criteria for advancement (Opportunities for advancement) } \\
\text { (e.g. transparent and freely accessible definitions of promotion criteria) }\end{array}$ & 35.4 & 33.3 & 36.2 & 41.6 & 5.66 \\
\hline $\begin{array}{l}\text { Performance appraisal (Performance measurement) } \\
\text { (e.g. yearly discussion with manager about individual performance and goal achievement) }\end{array}$ & 34.7 & 37.4 & 31.3 & 28.3 & $8.62 *$ \\
\hline $\begin{array}{l}\text { Informal feedback (Performance measurement) } \\
\text { (e.g. spontaneous praise or criticism from managers, peers, clients or team members) }\end{array}$ & 31.7 & 30.5 & 30.3 & 36.9 & 3.72 \\
\hline $\begin{array}{l}\text { Transparent internal job market (Opportunities for advancement) } \\
\text { (e.g. option to apply for all internally available positions) }\end{array}$ & 24.5 & 24.5 & 21.1 & 29.2 & 4.84 \\
\hline $\begin{array}{l}\text { Interpersonal skills training (Longer term business and leadership skill development) } \\
\text { (e.g. course on conflict-solving) }\end{array}$ & 23.4 & 24.2 & 20.1 & 27.0 & 3.82 \\
\hline $\begin{array}{l}\text { Clear description of career paths and job levels (Opportunities for advancement) } \\
\text { (e.g. transparent and freely accessible descriptions of internal IT career paths) }\end{array}$ & 22.1 & 18.1 & 35.9 & 19.7 & $43.9 * * *$ \\
\hline $\begin{array}{l}\text { Career counseling (Longer term business and leadership skill development) } \\
\text { (e.g. option to get individual advice on personal career development) }\end{array}$ & 21.2 & 26.9 & 21.7 & 17.6 & $40.0 * * *$ \\
\hline
\end{tabular}


Temporary assignments/secondments (Work arrangements)

(e.g. international assignment or job rotation to another function)

Informal career discussions (Longer term business and leadership skill development)

(e.g. option to discuss career issues outside the formal mid-year and year-end review)

Formal feedback (Performance measurement)

(e.g. regular $360^{\circ}$ feedback from managers, peers, clients and team members)

Formal career discussions (Longer term business and leadership skill development)

(e.g. mid-year and year-end discussions with line manager)

Career workshops (Longer term business and leadership skill development)

(e.g. sessions about self-management)

Online networking/communities (Sense of community)

(e.g. option to discuss career issues online with a group of IT professionals)

Outplacement (Work arrangements)

(e.g. support to find a new position outside the current organization)
*** significant ( $p=0.001$ level two-tailed); $* *$ significant at the $(p=0.01$ level two-tailed); $*$ significant $(p=0.05$ level two-tailed) Note: Swiss, UK and German totals do not sum to 1629 because there were respondents of other nationalities 
Table 5: OCM practice choices by category

\begin{tabular}{|c|c|c|c|c|c|c|c|c|}
\hline \multirow[b]{2}{*}{ Category } & \multirow{2}{*}{$\begin{array}{l}\text { Total number of } \\
\text { OCM practices in } \\
\text { category }\end{array}$} & \multicolumn{6}{|c|}{ Number of OCM practices chosen } & \multirow{2}{*}{$\begin{array}{l}\text { Mean and SD of } \\
\text { number chosen }\end{array}$} \\
\hline & & 0 & 1 & 2 & 3 & 4 & 5 & \\
\hline $\begin{array}{l}\text { Technical employability } \\
\text { training \& skill development }\end{array}$ & 3 & 210 & 639 & 639 & 141 & & & $1.44(0.82)$ \\
\hline $\begin{array}{l}\text { Longer term business and } \\
\text { leadership skill development }\end{array}$ & 7 & 287 & 606 & 459 & 212 & 59 & 6 & $1.49(1.06)$ \\
\hline $\begin{array}{l}\text { Opportunities for } \\
\text { advancement }\end{array}$ & 3 & 677 & 629 & 263 & 60 & & & $0.82(0.83)$ \\
\hline Performance measurement & 3 & 599 & 721 & 274 & 35 & & & $0.84(0.77)$ \\
\hline Work arrangements & 2 & 1240 & 355 & 34 & & & & $0.26(0.48)$ \\
\hline Sense of community & 1 & 1483 & 146 & & & & & $0.09(0.29)$ \\
\hline
\end{tabular}


Table 6: Multiple regression analyses testing predictors of OCM practice preferences

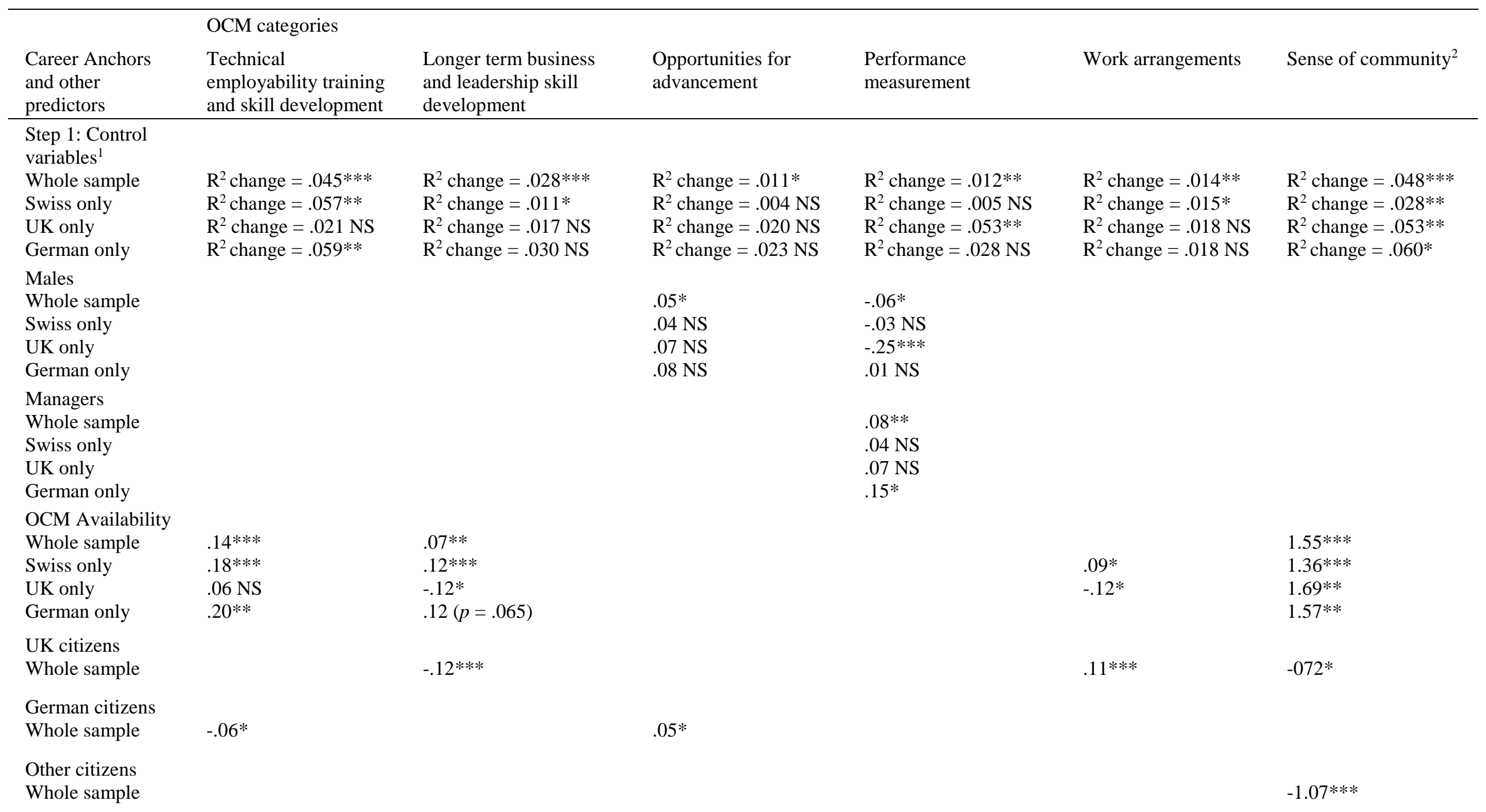


Step 2: Career

anchors

Whole sample

Swiss only

UK only

$\mathrm{R}^{2}$ change $=.047^{* * *}$

$\mathrm{R}^{2}$ change $=.044^{* * *}$

$\mathrm{R}^{2}$ change $=.042 * * *$

$\mathrm{R}^{2}$ change $=.026 * * *$
$\mathrm{R}^{2}$ change $=.033 * *$

$\mathrm{R}^{2}$ change $=.003 \mathrm{NS}$

$\mathrm{R}^{2}$ change $=.083^{* *}$

$\mathrm{R}^{2}$ change $=.057 *$

$\mathrm{R}^{2}$ change $=.033^{* *}$

$\mathrm{R}^{2}$ change $=.011 \mathrm{NS}$

$\mathrm{R}^{2}$ change $=.021 \mathrm{NS}$

$\mathrm{R}^{2}$ change $=.023 * * *$

$\mathrm{R}^{2}$ change $=.028^{* *}$

$\mathrm{R}^{2}$ change $=.021 * * *$

$\mathrm{R}^{2}$ change $=040$

$\mathrm{R}^{2}$ change $=.019 \mathrm{NS}$

change $=.083 * *$

$\mathrm{R}^{2}$ change $=.026 \mathrm{NS}$

Technical/

Functional

Whole sample

$.08 * *$

Swiss only

08*

UK only

$10 \mathrm{NS}$

German only

$.10 \mathrm{NS}$

$-.08 *$

$\mathrm{R}^{2}$ change $=.018 \mathrm{NS}$

Managerial

Competence

Whole sample

Swiss only

UK only

$-.21 * * *$

$-.20 * * *$

$-.24 * *$

German only

Geographical

Security

Whole sample

Swiss only

UK only

German only

Job Security

Whole sample

Swiss only

UK only

German only

$-.24 * *$

$19 * * *$

$.20 * * *$

Entrepreneurial

Creativity

Whole sample

Swiss only

UK only

German only

$\begin{array}{ll}.06 * & -.10^{* * *} \\ .06(p=.084) & -.10^{* *} \\ .04 \mathrm{NS} & -.01 \mathrm{NS} \\ .06 \mathrm{NS} & -.24^{* *}\end{array}$

$.14^{* * *}$

$17 * *$

$.08 \mathrm{NS}$
$-.10 * *$

$-.11^{* *}$

$-.19 * *$

-.07 NS

28*

$.21 \mathrm{NS}$

$.20 \mathrm{NS}$

$-.39 * *$

$-.53 * *$

$-.48(p=.062)$

$-.42 \mathrm{NS}$

$-.06 *$

$-.10 * *$

$.02 \mathrm{NS}$

$-.01 \mathrm{NS}$

$.19 *$ 
UK only

German only

Service/

Dedication

Whole sample

Swiss only

UK only

German only

$-.04 \mathrm{NS}$

Pure Challenge

Whole sample

Swiss only

$.06^{*}$

UK only

German only

Lifestyle

Whole sample

Swiss only

UK only

$.06(p=.085) \quad-.12 * *$

$.10(p=.095) \quad-.02 \mathrm{NS}$

$-.13(p=.076)$

Notes ${ }^{1}$ Age was also used as a control variable but was not significant in any analysis so is not shown.

${ }^{2}$ Because the dependent variable was binary, logistic regression was used. Coefficients shown are B rather than beta. $\mathrm{R}^{2}$ is Cox and Snell's statistic. $* * *$ significant $\left(p=0.001\right.$ level two-tailed); $* *$ significant $\left(p=0.01\right.$ level two-tailed); ${ }^{*}$ significant $(p=0.05$ level two-tailed) NS $=$ not significant. 